\title{
Gadget-Based Interactive Multimedia on Socio-Scientific Issues to Improve Elementary Students' Scientific Literacy
}

\author{
https://doi.org/10.3991/ijim.v15i01.13675
}

\author{
Suryanti ${ }^{(凶)}$, Wahono Widodo, Yoyok Yermiandhoko \\ Universitas Negeri Surabaya, Surabaya, Indonesia \\ suryanti@unesa.ac.id
}

\begin{abstract}
This study aimed to develop Socio-scientific Issues (SSI) gadgetbased interactive multimedia (GBIM) to improve elementary students' scientific literacy. The research is a Research and Development study with a 4-D model: define, design, develop, and disseminate. Data were collected using a validation sheet, observation sheet, and scientific literacy test. The GBIM was piloted on 25 suburban elementary school students in East Java. The data then were analyzed by using descriptive statistics: comparison with eligibility and $\mathrm{N}$-gain criteria. The result indicated that the GBIM is compatible as alternative learning media to improve elementary students' scientific literacy, that was: a) very valid with a score of 3.55 ; b) practical to use at "good criteria" with more studentcentered learning; c) effective, as there were positive responses about the learning activities and the students improved their scientific literacy from level 3 to level 4, with an $\mathrm{N}$-gain of 0.4 in the medium category.
\end{abstract}

Keywords - Gadget-based interactive multimedia, socio-scientific issues, scientific literacy

\section{Introduction}

Scientific literacy is an essential competency required by individuals to actively contribute and participate in creating a better life in this modern era. As a reference, [1] describes one of the four skills needed in the $21^{\text {st }}$ century for the future generation to meet the globalization challenges due to information and technology advances, namely digital age literacy, which includes scientific literacy. Science is strongly associated with everyday life. Therefore, scientific education needs to ensure that the next generation is scientific literate [2]. However, the scientific literacy of Indonesian students has not shown encouraging results. This is reflected in the results of the scientific literacy test in 2018, where Indonesian students were ranked 71 out of 79 countries and their average score was below the average score for the whole country tested by OECD.

Science can be learned naturally and effectively in the context of Socio-scientific Issues (SSI) [3]. SSI consists of social dilemmas that hold conceptual or technical 
relation to science [4-5]. Reference [6-8] states that SSI is comprised of problems that are open to multiple solutions. The use of SSI in education may improve students' skills in making decisions. SSI teaches metastrategic skills such as evaluation, making decisions and arguments [9]. In this case, SSI appears as a key role of scientific literacy [10]. SSI prepares individuals to develop an alternative solution as well as ethical and scientific reasoning skills [11].

Scientific literacy is the ability to be involved in science-related issues and scientific ideas as a reflective citizen. Someone who has scientific literacy is willing to be involved in issues related to science and technology which require competencies to explain scientific phenomena; evaluate and design scientific research; interpret scientific data and evidence [12].

There is some research regarding the use of SSI in learning activities as seen in reference [13] suggesting that argumentation exercise should be done. Thus, it will allow students to strongly hold onto their ideas about SSI, evaluate various alternatives and allow them to make value-oriented decisions in the realm of intuitive education. According to [8], Korean middle school teachers state that SSI is necessary for the science curriculum. Besides, the result shows that using SSI as in a learning context has a significant impact on students' critical thinking skills [14-16].

Upper elementary students (grades 4, 5, and 6) are those ranging between 10-13 years old. Based on that age range, those students are included as generation Z. Generation Z [17] encompasses kids or teenagers born in 1995-2012. Generation Z is currently in school and has several characteristics as follows: expert in understanding technology, multi-tasker, socially open through the use of technology, fast and impatient, interactive, and vigorous [18]. Time Magazine stated that generation $\mathrm{Z}$ is attracted to technology and skill-based learning. Technology is indispensable for Generation Z. This generation grows in the era of unlimited access to information, whenever and wherever, with unceasingly new trend. In general, they have access to cell phone or tablet at a very early age and is raised using one or more computerized device. Thus, device-based learning will be even more massive, because generation $\mathrm{Z}$ prefers learning like this.

Responsible Research and Innovation (RRI) stated that social actors and scientists should be mutually responsive to create a better understanding of science and social issues (including risk, benefit, and obstacle). Thus, it will possibly instill science and technology advancement in the community [19-20]. Information technology competency and teacher's communication are constantly regarded as an important element in the development of education. It can be regarded as the required skills and knowledge for teachers to integrate the use of technology devices more as a learning tool into their daily practices [21].

In developed countries such as Australia, the need to integrate the use of information and communication technology (ICT) into the science curriculum is explicitly mentioned in the Australian School Science Education National Action Plan. In that plan, it is said that students study science by seeking perceptions from various sources starting from direct investigation to web surfing [22]. Here is one of the findings of the studies related to ICT application in learning activity. Reference [23] states that ICT is used to develop effective science learning. The use of computer-based media 
with many alternatives effectively helps students understand the chemical phenomenon deeper [24].

The use of technology-based learning medium is an integration of ICT into learning activity. One of the suitable media used to improve learning for Generation $\mathrm{Z}$ is interactive multimedia. In teaching any kind of subject, through its efficiency and impact, digital application has a relatively big role since it contributes significantly to the didactic principal implementation and teaching goals realization [25-27]. Course delivery supported by the use of multimedia attracts students and affects learning development and creation of the right conception [28]. The use of multimedia and virtual reality makes the world seem like no one ever sees before [29-31].

The use of multimedia in learning emphasizes experience and learning ability from a variety of nonverbal representations such as pictures, animation, and narration towards students [32]. Besides, meaningful learning in the use of multimedia is realized when students pick up relevant information, coherent principles, modality, individual differences, etc., which to this day, those principles have become the main guideline to design multimedia instruction.

A variety of research has observed the application of multimedia in science learning and its effectiveness in science course teaching. The effectiveness may improve due to the increased motivation and interest in this course due to the use of different multimedia as a learning material of a higher level than visualization of abstract concepts offered in visual media by focusing on essential science concepts and education [33-36]. Empirical research showed that the use of computer-based media with multiple representatives effectively helps students understand the chemical phenomenon better [24]. The use of interactive multimedia contributes positively to minimize students' negative behavior during learning activity in school, especially in physics [37]. Interactive White Board (IWB) is reported to be effective for teachers to interact and incorporate digital content and multimedia learning sources in class [38-40]. Clayton \& Murphy [41] state that the right use of gadgets tend to boost students learning while a Huda et al. [42] find students using gadgets to be productive if done correctly. This study aimed to develop SSI Gadget-based interactive multimedia to improve elementary students' scientific literacy skills.

\section{$2 \quad$ Method of Research}

\subsection{Research design}

This research was a Research and Development ( $R$ \& D) with a 4-D model initiated by Thiagarajan, Semmel, and Semmel [43]. The developed product is SSI-GBIM on the topic of Healthy Food for fourth-grade elementary students. Through the define and design stages, an SSI-GBIM prototype was produced with the following characteristics: 1) The GBIM is packaged in the form of an application program that runs on an Android-based device; 2) GBIM contains SSI in food-related health, namely sweetened condensed milk, cases of malnutrition, cases of diarrhea, and cases of diabetes; 3) Based on SSI, GBIM encourages students to carry out simple investigations 
and study science concepts through interactive multimedia; 4) There is a scientific literacy check feature.

Figure 1 shows some of the screenshots of SSI and Gadget-based IM under the theme of Healthy Food.
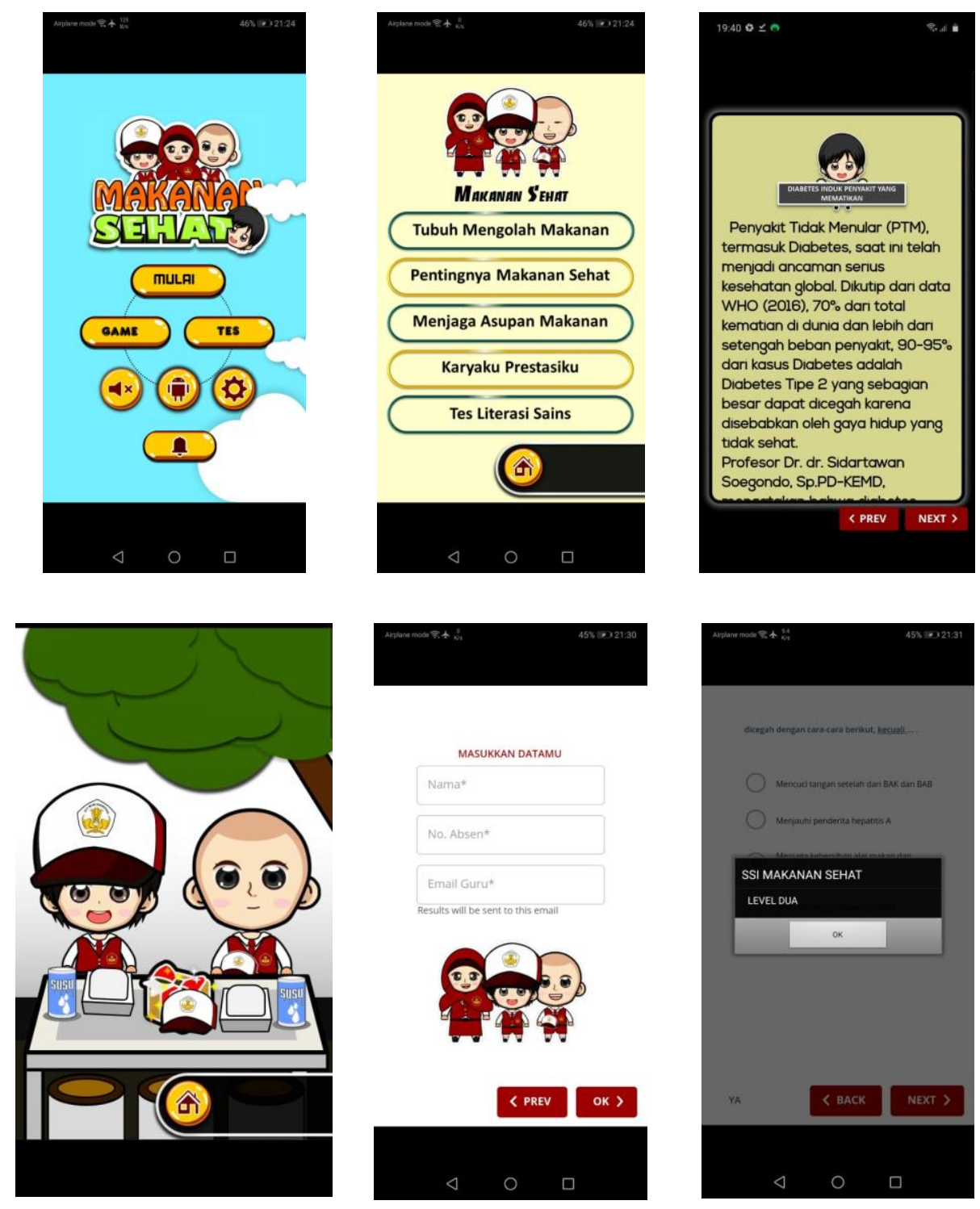

Fig. 1. IM-SSI-Gadget interface 


\subsection{Participants}

This research was conducted to fourth-grade elementary students of SDN RumpukLamongan with the total number of 23 students as a respondent for model testing with one group pre-test post-test design [44].

\subsection{Instrument}

Instruments used in this study consisted of a validation sheet, observation sheet, scientific literacy test, and student questionnaire response.

Validation sheet: The validation sheet was used by validators to assess the quality of the developed SSI-GBIM from interface, content presentation, design, content appropriateness, ease of use, and update.

Observation sheet: The observation sheet as a guide to assess students' activities during a lesson as follows (a) paying attention to the teacher's explanation or instruction, (b) doing a research activity or problem-solving, (c) taking notes/doing activities which involve writing on a notebook, (d) doing activities using the developed media (via students' cell phone), (e) discussing with peers or teacher, (f) googling answers, and (g) playing games.

Scientific literacy test: The scientific literacy test comprising 20 multiple choice questions designed according to the cognitive demand level in scientific literacy assessment. It is classified into three taxonomy dimensions as follows:

a) Low. Students with low scientific literacy can only conduct a one-step procedure such as recalling facts, definitions, principles, or concepts and finding the gist of a graphic or table.

b) Medium. Students with medium scientific literacy can use and apply their conceptual knowledge to describe and explain a phenomenon, choose a suitable procedure by incorporating two or more steps, organize or present data, interpret or use simple data or graphics.

c) High. Students with high scientific literacy can analyze complex data or information, synthesize or evaluate evidence, prove arguments stated by various sources, develop planning or steps to solve a problem.

The 20 multiple-choice questions consisted of eight questions with low cognitive demand, six questions with medium cognitive demand, and six questions with high cognitive demand. Question validation analysis using SPPS resulted in 17 valid questions and 3 invalid questions ( $\mathrm{r}$ count $<0.325$ ). The invalid questions were not used. Question reliability measurement using KR-20 resulted in 0.430 in the medium category.

Student questionnaire response: The student questionnaire response sheet was used to determine student responses towards scientific learning activity using MMI that consisted of content, scientific literacy test, and instruction. 


\subsection{Data analysis}

Data analysis was used to describe the validity, practicality, and effectiveness of the SSI-GBIM.

Validity: Validity data was obtained from the assessment by two media experts as a validator using the validation sheet as the instrument. Data compared with interactive multimedia feasibility assessment criteria [44].

Practicality: Data on the practicality of using SSI-GBIM was obtained from students' activity during the lesson. The analysis of the observation result of student's activity was descriptive quantitative with the percentage of time for an activity against the total time.

Effectivity: Data on the SSI-GBIM effectiveness was obtained from scientific literacy tests and student's responses. The result of the scientific literacy test was served in the form of scoring and leveling. The score given to each level referred to the minimum score of the master level of PISA 2013 which was then processed and formulated using a scoring formula with different weight items. Thus, the score ranges were obtained for each category of scientific literacy level [61]. From that calculation, score and level were categorized as follows: 0-2 (low level); 3-12 (level 1); 1328 (level 2); 29-43 (level 3); 44-59 (level 4); 60-78 (level 5); and 79-100 (level 6). Scientific literacy improvement was described using normalized gain (N-gain) and its criteria [45-46]. The data of students' responses towards learning using SSI and Gadget-based IM were analyzed using a descriptive statistic in percentage.

\section{$3 \quad$ Results and Discussion}

\subsection{Validity}

The prototype of the SSI-GBIM was validated by two media experts. The validation result is shown in Table 1.

Table 1. The Result of Validity Assessment of the SSI-GBIM

\begin{tabular}{|l|c|l|}
\hline \multicolumn{1}{|c|}{ Aspect of scoring } & \multicolumn{2}{c|}{ Validity } \\
\cline { 2 - 3 } & Score & \multicolumn{1}{c|}{ Criteria } \\
\hline Content suitability for elementary students' development & 3.50 & Very valid \\
\hline Material served suitable for Elementary students' characteristic & 3.00 & Valid \\
\hline Interface & 3.75 & Very valid \\
\hline Design of SSI-Gadget-based MMI & 3.75 & Very valid \\
\hline Ease of use and update & 3.75 & Very valid \\
\hline Median & $\mathbf{3 . 5 5}$ & Very valid \\
\hline
\end{tabular}

Validators' assessment result shows that the SSI-GBIM acquired a median of 3.55 (from $1-4$ score interval) and is categorized as very valid. The prototype of SSIGBIM had also been revised based on the validators' input, especially on the technical aspect, namely, the character's voice over (A'laa, Rakha, and Gugun) in the application that were quite similar to each other. Therefore, the voice of those three charac- 
ters should be made different. Besides, bugs were still found in that application. The bugs included some unheard audios, too small fonts, and two loading pages in that application.

\subsection{Practicality}

The practicality was observed from students' activity during the lesson using theGBIM. The observation of overall students' activity during the lesson can be seen in Table 2.

Table 2. The Percentage of Students' Activity

\begin{tabular}{|c|l|c|c|c|c|}
\hline \multirow{2}{*}{ No. } & \multicolumn{1}{|c|}{ Observation Category } & \multicolumn{3}{c|}{ Percentage (\%) } & \multirow{2}{*}{ Median } \\
\cline { 3 - 4 } & & $\begin{array}{l}\text { Pert. I } \\
1\end{array}$ & $\begin{array}{l}\text { Pert. II } \\
\text { tion }\end{array}$ & Pert. III & \\
\hline 2 & Doing a research activity or problem solving & 23 & 22 & 23 & 23 \\
\hline 3 & $\begin{array}{l}\text { Taking notes/doing activities which involve writing on } \\
\text { notebook }\end{array}$ & 16 & 16 & 14 & 13 \\
\hline 4 & $\begin{array}{l}\text { Doing activities using the developed SSI-GBIM (via } \\
\text { students' cell phone) }\end{array}$ & 28 & 28 & 29 & 28 \\
\hline 5 & Discussing with peer or teacher & 11 & 11 & 11 & 11 \\
\hline 6 & Googling answers & 7 & 7 & 7 & 7 \\
\hline 7 & Playing games & 3 & 3 & 3 & 3 \\
\hline
\end{tabular}

Table 2 shows that by using the SSI-GBIM, learning activities tend to be studentcentered. The percentage shows that the students were very enthusiastic about participating in the learning activity using the developed SSI and Gadget-based IM.

\subsection{Effectivity}

The effectivity of using the SSI-GBIM was seen from the N-gain scores of scientific literacy and students' responses. Students' scientific literacy for each cognitive demand is shown in Table 3.

Table 3. Students' Capacity of Scientific Literacy in each Cognitive Demand

\begin{tabular}{|c|c|c|c|c|}
\hline Cognitive Demand & Activity & Median (\%) & N-Gain & Criterion \\
\hline \multirow[t]{2}{*}{ Low (L) } & Pre-test (R1) & 29 & \multirow{2}{*}{0.3} & \multirow{2}{*}{ Medium } \\
\hline & Post-test (R2) & 51 & & \\
\hline \multirow[t]{2}{*}{ Medium (M) } & Pre-test (S1) & 29 & \multirow{2}{*}{0.3} & \multirow{2}{*}{ Medium } \\
\hline & Post-test (S2) & 52 & & \\
\hline \multirow[t]{2}{*}{$\operatorname{High}(\mathrm{H})$} & Pre-test (T1) & 36 & \multirow{2}{*}{0.3} & \multirow{2}{*}{ Medium } \\
\hline & Post-test (T2) & 57 & & \\
\hline
\end{tabular}

Based on Table 3, students' capacity in doing the scientific literacy test for each cognitive demand was $<50 \%$ during the pretest. The median increased during the post-test to $51 \%$ for R2, $52 \%$ for S2, and $57 \%$ for $\mathrm{T} 2$. The capacity of scientific litera- 
cy being assessed encompasses students' knowledge, context, and scientific competency. The result of students' scientific literacy test consisting of knowledge, context, and competency is shown in Table 4.

Table 4. The Result of Students' Scientific Literacy Test

\begin{tabular}{|c|c|c|c|c|c|c|}
\hline \multirow{3}{*}{\begin{tabular}{|c|}
$\begin{array}{c}\text { Student's } \\
\text { Code }\end{array}$ \\
$\mathrm{AFN}$
\end{tabular}} & \multicolumn{2}{|c|}{ Score } & \multicolumn{2}{|c|}{ Level } & \multirow{2}{*}{\multicolumn{2}{|c|}{ N Gain }} \\
\hline & Pre-Test & Post Test & Pre-Test & Post Test & & \\
\hline & 30 & 62 & 3 & 5 & 0.5 & Medium \\
\hline $\mathrm{AP}$ & 28 & 54 & 2 & 4 & 0.4 & Medium \\
\hline BAI & 18 & 58 & 2 & 4 & 0.5 & Medium \\
\hline DFF & 21 & 56 & 2 & 4 & 0.4 & Medium \\
\hline ES & 51 & 75 & 4 & 5 & 0.5 & Medium \\
\hline FS & 23 & 35 & 2 & 3 & 0.2 & Low \\
\hline FKA & 29 & 47 & 3 & 4 & 0.3 & Medium \\
\hline FEH & 36 & 52 & 3 & 4 & 0.3 & Medium \\
\hline FAS & 30 & 45 & 3 & 4 & 0.2 & Low \\
\hline FRI & 34 & 47 & 3 & 4 & 0.2 & Low \\
\hline IADL & 20 & 58 & 2 & 4 & 0.5 & Medium \\
\hline $\mathrm{KN}$ & 20 & 55 & 2 & 4 & 0.4 & Medium \\
\hline NAH & 35 & 55 & 3 & 4 & 0.3 & Medium \\
\hline NDS & 24 & 43 & 2 & 3 & 0.3 & Medium \\
\hline OFI & 21 & 50 & 2 & 4 & 0.4 & Medium \\
\hline $\mathrm{RP}$ & 31 & 67 & 3 & 5 & 0.5 & Medium \\
\hline RAPP & 22 & 58 & 2 & 4 & 0.5 & Medium \\
\hline RKN & 34 & 46 & 3 & 4 & 0.2 & Low \\
\hline SAN & 56 & 63 & 4 & 5 & 0.2 & Low \\
\hline SAA & 36 & 57 & 3 & 4 & 0.3 & Medium \\
\hline VA & 45 & 72 & 4 & 5 & 0.5 & Medium \\
\hline YF & 39 & 55 & 3 & 4 & 0.3 & Medium \\
\hline AS & 21 & 54 & 2 & 4 & 0.4 & Medium \\
\hline \begin{tabular}{|l} 
Average \\
\end{tabular} & 31 & 55 & 3 & 4 & 0.4 & Medium \\
\hline
\end{tabular}

Based on the data in Table 4, there are some scores and level improvements in scientific literacy after the science learning process using SSI-GBIM. The increase of students' scientific literacy score indicated by an N-gain of 0.4 in the medium category. The average level increases from level 3 to level 4 . Students in level 4 have an effective capacity that works in situations or problems involving explicit phenomenon, requiring them to make a conclusion about the role of science or technology, choose and integrate the definition from different disciplines of science or technology and incorporate them directly to the aspects of life, make an action and communicate based on scientific knowledge, decision, and the fact [47]. The score and level improvements of students' scientific literacy cannot be separated from students' activity during the learning activity and their response toward the SSI-GBIM used in the lesson. The overall response of students is written in Table 5. 
Table 5. Students' response towards the quality of SSI-GBIM

\begin{tabular}{|c|c|c|}
\hline No. & Aspect & $\begin{array}{c}\text { Percentage } \\
(\%)\end{array}$ \\
\hline \multicolumn{3}{|c|}{ Content } \\
\hline 1 & Attractiveness of the SSI-GBIM interface & 100 \\
\hline 2 & Attractiveness of the SSI-GBIM content & 100 \\
\hline 3 & Easy-to-understand material & 100 \\
\hline 4 & Easy-to-understand graphic/animation/video & 100 \\
\hline 5 & Easy-to-operate of the SSI-GBIM & 98 \\
\hline 6 & Link on the SSI-GBIM that works well & 99 \\
\hline 7 & Clear audio (narration) & 100 \\
\hline \multicolumn{3}{|c|}{ Scientific Literacy Test } \\
\hline 1 & Relevant material with the concept discussed in the SSI-GBIM & 100 \\
\hline 2 & The tests given are new and have never been used before & 100 \\
\hline 3 & The tests given require "high concentration" & 100 \\
\hline 4 & Scientific literacy test's response towards users' click is understandable & 100 \\
\hline 5 & "Your Scientific Literacy Level Check" page runs well & 100 \\
\hline \multicolumn{3}{|c|}{ Instruction } \\
\hline 1 & Attractive interface & 100 \\
\hline 2 & Easy-to-understand instruction content & 100 \\
\hline 3 & Helpful instruction content for users & 100 \\
\hline 4 & Clear audio (narration) & 100 \\
\hline
\end{tabular}

Based on Table 5, almost all aspects received a score of $100 \%$ from students' responses except for easy-to-operate SSI and Gadget-based IM (98\%) and link on the SSI-GBIM that works well (99\%). The high percentage means that students respond well to the learning activity using the developed SSI-GBIM. Along with those aspects, students were also allowed to make comments on the learning activity using the developed SSI-GBIM by leaving their thoughts in the comment section available. From that comment section, students expressed that the learning activity using SSI and Gadget-based IM was so interesting since it used a cell phone as a medium. Learning became so much fun and not boring. Students got to learn new knowledge, the icon on the application was cute and the colors were attractive. Learning with the cell phone was so fun and fascinating. There were games, fun applications, complete subject matter, study matter, and questions and it was easier to understand.

The result is in line with a statement by Piaget stating that children are naturally curious and they always try to understand the world around them. That curiosity is the one that motivates them to develop a certain understanding regarding the environment they are living in. In the developed SSI-GBIM, there are SSI served in each sub discussion chapter. The SSI explained are hot issues in society and the media. Those SSI are not solely used to contextualize the learning activity, yet, it stimulates students' curiosity towards those issues. After observing those SSI, students were asked to learn scientific concepts relevant to the context of SSI. On top of that, SSI-GBIM also offers research activity for the students to strengthen and apply the concepts they already-learned; thus, learning becomes much more meaningful. This is in line with Meyer and Moreno's research [48] stating that multimedia takes a role to create a 
meaningful learning activity. A meaningful learning may help students grasp onto knowledge and store them in a long-term memory. Moreover, it will help students apply the knowledge they have into real, new, and different situations. This is in line with Eliyawati's research [49] stating that the use of multimedia can enhance students' scientific literacy to medium category. Fan \& Geelan [50] add that the use of multimedia in learning contributes to the development of high-quality scientific education and improve students' scientific literacy in the future. Latif [51] argues that the use of scientific literacy-based multimedia may improve students' scientific literacy.

The result indicated that the SSI-GBIM with Healthy Food as a Theme is effective to improve students' scientific literacy. This shows that Indonesian students' scientific literacy can be improved in line with the effort of improving scientific literacy through research [45] and [52]. The result also showed creative ways that attract students and instill them with the desire to read, think, investigate, and make decisions regarding the socio-scientific issues given. The creative ways done were using flipbook [53] and blog [52]. Current students in school are Generation Z students, a generation born in the 2000s. This generation tends to be inseparable from gadget. This condition is used by the teacher as a huge opportunity to benefit from the gadget as a Science learning medium. This result is in line with Clayton and Murphy's research [54], stating that the proper use of gadgets may stimulate students learning. Gadgets and games have a positive impact on the world of education [55-61]. Anshari et al. [42] add that students with gadgets and games can be productive and successful as long as it has the appropriate term of use.

\section{Conclusion}

Based on the research and discussion above, it can be concluded that the SSIGBIM with Healthy Food as a Theme is feasible to improve the capacity of Elementary students' scientific literacy, as it is proven to acquire a validation score of 3.55 (from $1-4$ score interval) with a criterion of very valid and a practicality of good, seen from student's activity which is dominantly filled with students spending their time using the developed media (via their gadget) with a percentage of $28 \%$. The method is considered effective as seen from the positive response towards the learning activity using SSI and Gadget-based interactive multimedia and students' scientific literacy improvement from level 3 to level 4, with N-gain amounting to 0.4 (at medium category). This result shows that the SSI-GBIM can be used as an alternative learning medium to improve elementary students' scientific literacy skills.

\section{Acknowledgement}

The result of this research is a product of basic research supported by the Postgraduate program of Universitas Negeri Surabaya. We would like to thank all colleagues who supported and assisted the process of this research. 


\section{References}

[1] NCREL \& Metiri Group. (2003). 21st century skills: literacy in the digital age. http://www.ncrel.org/engauge.org/engauge [23 December 2018].

[2] Binggeli, B. (2013). Integrated Scientific 1. Brevard Public Schools. pp. 5.

[3] Sharkawy, A. (2009). Moving beyond the lone scientist: helping 1st-grade students appreciate the social context of scientific work using stories about scientists. Journal of Elementary Scientific Education, 21, 67-78. https://doi.org/10.1007/bf03174716

[4] Sadler, T. D. (2004). Informal reasoning regarding socio-scientific issues: A critical review of research. Journal of Research in Scientific Teaching, 41 (5), 513-536. https://doi.org/ $10.1002 /$ tea.20009

[5] Morris, H. (2014). Socio scientific issues and multi-disciplinarity in school scientific textbooks. International Journal of Scientific Education, 36 (7), 1137-1158.

[6] Zeidler, D. L. (2003). The role of moral reasoning on socio-scientific issues and discourse in scientific education. The Netherlands: Kluwer Academic Press. https://doi.org/10. 1007/1-4020-4996-x

[7] Elliot, Paul. (2010). Scientific and literacy in the elementary school. A research-intopractice series produced by a partnership between the literacy and numeracy. Secretariat and the Ontario Association of Deans of Education.

[8] Lee, H., Abd-El-Khalick, F., \& Choi, K. (2006). Korean scientific teachers' perceptions of the introduction of socio-scientific issues into the scientific curriculum. Canadian Journal of Scientific, Mathematics and Technology Education, 6(2), 97-117. https://doi.org/10. $\underline{1080 / 14926150609556691}$

[9] Sakschewski, M., Eggert, S., Schneider, S., \& Bögeholz, S. (2014) Students' socioscientific reasoning and decision-making on energy-related issues-development of a measurement instrument. International Journal of Scientific Education, 36(14), 2291-2313. https://doi.org/10.1080/09500693.2014.920550

[10] Kolst $\varnothing$, S. D. (2001). Scientific literacy for citizenship: tools for dealing with the scientific dimension of controversial SSI. Scientific Education, 85(3), 291-310. https://doi.org/10. $1002 /$ sce. 1011

[11] Ministry of National Education of Turkey (MoNE). (2013). Elementary school's scientific education curriculum for grades 3, 4, 5, 6, 7, and 8. Ankara: Milli Eğitim Bakanlığı Talim ve Terbiye Kurulu Başkanlığı. Retrieved from http://ttkb.meb.gov.tr/.

[12] OECD. (2016). PISA 2015 assessment and analytical framework: scientific, reading, mathematic and financial literacy. http://doi.org/10.1787/9789264255425-en.

[13] Acar, O., Turkmen, L., \& Roy-Choudhury, A. (2010). Student difficulties in socio-scientific argumentation and decision-making research findings: crossing the borders of two research lines. International Journal of Scientific Education, 32 (9), 1191-1206. https://doi.org/10.1080/09500690902991805

[14] Eggert, S., Oster Meyer, F., Hassel horn, M., \& Bögeholz, S. (2012). Socio-scientific Decision making in the scientific classroom: the effect of embedded metacognitive instructions on students' learning outcomes. Research Article Education Research International, https://doi.org/10.1155/2013/309894

[15] Tal, T. \& Kedmi, Y. (2006). Teaching socio-scientific issues: classroom culture and students' performances. Cultural Scientific Education. https://doi.org/10.1007/s11422-0069026-9

[16] Pratiwi, Y.N., Rahayu, S., and Fajaroh, F. (2016). Socio-scientific issues (SSI) in rection retes topic and its effect on critical thinking skills of high school students. Journal Pendidi- 
kan IPA Indonesia (JPII) 5 (2) (2016) 164-170. https://doi.org/10.15294/jpii. v7i1.9928

[17] Schroer, W. (2008). Defining, managing, and marketing to generations X, Y, and Z. The Portal, 10, 9. Tersedia di: http://goo.gl/Fc40dB. Diakses tanggal 19 Maret 2019.

[18] Aparici, R. (2010). Conectados en el ciberespacio. Madrid: UNED.

[19] Owen, R., Macnaghten, P., \& Stilgoe, J. (2012). Responsible research and innovation: From scientific in society to scientific for society, with society. Scientific and Public Policy, 39, 751-760. https://doi.org/10.1093/scipol/scs093

[20] Von Schomberg, R. (2013). A vision of responsible innovation. In: R. Owen, M. Heintz, \& J. Bessant (Eds.), Responsible innovation. London: Wiley, forthcoming. https://doi.org/10 $.1002 / 9781118551424$

[21] Suárez-Rodríguez, J.M., Almerich, G., Díaz-García, I. \& Fer nán dez-Piqueras, R. (2012). Competencies del professorate en las TIC. Influencia de factores personal's y contextuales. Universitas Psychological, 11(1), 293-309. Tersedia di: http://goo.gl/VCz6jD. Daises' tanggal 19 Maret 2019. https://doi.org/10.11144/javeriana.upsy11-1.cpif

[22] Goodrum, D. \& Rennie, L. (2007). Australian school scientific education: National Action Plan 2008-2012, Volume 1, The National Action Plan. Canberra: Department of Education, Training and Youth Affairs.

[23] Hackling, M. \& Prain, V. (2005). Primary connections: stage 2 trial-research report. Canberra: Australian Academy of Scientific.

[24] Levy, S. T., \& Wilensky, U. (2009). Crossing levels and representations: the connected chemistry (cc1) curriculum. Journal of Scientific Education and Technology, 18(3), 224242. https://doi.org/10.1007/s10956-009-9152-8

[25] Webb, M. (2005). Affordances of ICT in an integrated pedagogy. International Journal of Scientific Education, 27 (6), 705-735.

[26] Lamanauskas, V., \& Vilkonis, R. (2007). Information communication technologies in natural scientific education: situational analysis and prospects in baltic countries. Journal of Baltic Scientific Education, 6 (2), 35-49.

[27] Shi, W. Z. (2013). The effect of peer interactions on quantum physics: a study from china. Journal of Baltic Scientific Education, 12 (2), 152-158.

[28] Chen, Y. T. (2012). A study of learning effects on e-learning with interactive thematic video. Journal of Educational Computing Research, 47 (3), 279-292. https://doi.org/10. 2190/ec.47.3.c

[29] McClintock, R. (2001). Experience and innovation: reflections on emerging practice with new media in education. Journal of Educational Computing Research, 25 (1), 95-104. https://doi.org/10.2190/7eef-1mhc-urtg-6nm6

[30] Bílek, M. (2010). Natural Scientific education in the time of virtual worlds. Journal of Baltic Scientific Education, 9 (1), 4-5.

[31] Aberšek, B. (2013). Cogito ergo sum homo machine? Journal of Baltic Scientific Education, 12 (3), 268-270.

[32] Yang, F.Y., Chang, C.Y., Jien, W.R., Jien, Y.T., \& Tseng, Y.H. (2013). Tracking learners' visual attention during a multimedia presentation in a real classroom. Journal of Computers \& Education, 62, 208-220. https://doi.org/10.1016/j.compedu.2012.10.009

[33] Thube, S. G., \& Shaligram, A. D. (2007). Effectiveness of computer assisted teaching of geometrical optics at undergraduate level. Physics Education, January - March 2007, 263272.

[34] Aggul, F., Yalcin, M., Acikyildiz, M., \& Sonmez, E. (2008). Investigation of effectiveness of demonstration-simulation based instruction in teaching energy conservation at 7 th grade. Journal of Baltic Scientific Education, 7 (2), 64-77. 
[35] Bakaç, M., Kartal Taşoğlu, A., \& Akbay, T. (2011). The effect of computer assisted instruction with simulation in scientific and physics activities on the success of student: electric current. Eurasian Journal of Physics and Chemistry Education, 1 (Special Issue), 3442.

[36] Ferreira, C., Baptista, M., \& Arroio, A. (2013). Teachers' pedagogical strategies for integrating multimedia tools in scientific teaching. Journal of Baltic Scientific Education, 12 (4), 509-524.

[37] Záhorec. J., Hašková. A., \& Bílek. M. (2014). Impact of multimedia assisted. 361-380.

[38] Betcher, C. \& Lee, M. (2009). The interactive whiteboard revolution. Victoria, Australia: ACER Press.

[39] Hennessy, S., Deaney, R., Ruthven, K. \& Winterbottom, M. (2007). Pedagogical strategies for using the interactive whiteboard to foster learner participation in school scientific. Learning, Media and Technology, 32(3), 283-301. https://doi.org/10.1080/ 17439880701511131

[40] Murcia, K. (2008). Teaching for scientific literacy with an interactive whiteboard. Teaching Scientific, 54(4), 17-21.

[41] Clayton, Kara E \& Murphy, Amanda. (2016). Smartphone apps in education: students create videos to teach smartphone use as tool for learning. The Journal of Media Literacy Education Vol. 8 (2), pp. 99-109.

[42] Anshari, M, Almunawar, MN, Shahrill, Masitah, Wicaksono, DK, dan Huda, M. (2017). Smartphones usage in the classrooms: learning aid or interference? Journal of Education and Information Technologies, Vol 22 (6) pp. 3063-3079. https://doi.org/10.1007/ s10639-017-9572-7

[43] Thiagarajan, S., Semmel, D. S \& Semmel, M. I. 1974. Instructional Development for Training Teachers of Expectional Children. Minneapolis, Minnesota: Leadership Training Institute/Special Education, University of Minnesota.

[44] Ratumanan, G.T. \& Laurens. (2011). Evalusi hasil yang relevan dengan memecahkan problematika belajar dan mengajar. Bandung: CV Alfabeta.

[45] Inzanah, I., Muslim, I., dan Wahono W. (2014). Pengembangan perangkat pembelajaran IPA berbasis kurikulum 2013 untuk melatih literasi sains siswa SMP. Jurnal Penelitian Pendidikan Sains. 4(1), 425-499. https://doi.org/10.26740/jpps.v4n1.p459-467

[46] Hake, R, R. (1999). Analyzing change/gain scores, area-d American education research association's devision. D, Measurement and Research Methodology.

[47] OECD. (2018). PISA 2018 Insight and Interpretations. Paris: OECD.

[48] Mayer, R.E. and Moreno, R. (2003). Nine ways to reduce cognitive load in multimedia learning. Education Psychologist, 38(1), 43-52. https://doi.org/10.1207/s1532 6985ep3801_6

[49] Eliyawati. (2013). Multimedia Pembelajaran Sel Volta Bermuatan Sains dan Teknologi Nano pada Konteks Sel Surya untuk Meningkatkan Literasi Sains. (Tesis). Sekolah Pascasarjana Universitas Pendidikan Indonesia, Bandung. https://doi.org/10.33394/jps.v1i1.516

[50] Fan, X. dan Geelan, D. (2012). Effectiveness of active instruction with simulation on misconception in senior secondary physics classroom in Mainland China. Paper presented at the 43rd Annual ASERA Conference, University of the Sunshine Coast.

[51] Latif, A. dan Permanasari, A. (2015). Pengembangan multimedia pembelajaran berbasis literasi sains untuk siswa SMP pada tema teknologi. Edusains, 7(2), 160-171. https://doi.org/10.15408/es.v7i2.1761

[52] Maghfirothi, N.L., Mitarlis, dan Widodo, W. 2013. Pengembangan flip book IPA terpadu bilingual dengan tema minuman berkarbonasi untuk kelas VIII SMP. E-Pensa 1 (3). 
[53] Zhang, X., Meng, Y., de Pablos, P. O., \& Sun, Y. (2017). Learning analytics in collaborative learning supported by Slack: From the perspective of engagement. Computers in Human Behavior, 1-9.

[54] Clayton and Murphy. (2016). Smartphone apps in education: students create videos to teach smartphone use as tool for learning. The Journal of Media Literacy Education, 8(2), 99-109.

[55] Widodo, W., Suryanti, Sudibyo, E., and Sari, D.A.P. (2018). Socio-scientific issues in gadged: Interactive multimedia to increase z-generation scientific literacy. International Conference on Scientific, Technology, Education, Arts, Culture and Humanity (STEACH). Published by Atlantis Press. https://doi.org/10.2991/steach-18.2019.8

[56] Lestari, I., Maksum, A., \& Kustandi, C. (2019). Mobile Learning Design Models for State University of Jakarta, Indonesia. International Journal of Interactive Mobile Technologies: 13(9), 152-171. https://doi.org/10.3991/ijim.v13i09.10987

[57] Yunita, A., Nursechafia, Setiawan, E., \& Nugroho, H. (2018). The Relationship between Mobile Phone Usage in Classroom and Academic Achievement in College Life. International Journal of Interactive Mobile Technologies: 12(8), 96-103. https://doi.org/10. 3991/ijim.v12i8.9530

[58] Fawareh, H.M.A. \& Jusoh, S. (2017). The Use and Effects of Smartphones in Higher Education. International Journal of Interactive Mobile Technologies: 11(6), 103-111.

[59] Kalogiannakis, M., \& Papadakis, S. (2019). Evaluating pre-service kindergarten teachers' intention to adopt and use tablets into teaching practice for natural sciences. International Journal of Mobile Learning and Organization, 13(1), 113-127. https://doi.org/10. 1504/ijmlo.2019.10016617

[60] Papadakis, S. (2018). Evaluating pre-service teachers' acceptance of mobile devices with regards to their age and gender: a case study in Greece. International Journal of Mobile Learning and Organization, 12(4), 336-352. https://doi.org/10.1504/ijmlo.2018. 10013372

[61] Papadakis, S. (2020). Evaluating a game-development approach to teach introductory programming concepts in secondary education. International Journal of Technology Enhanced Learning, 12(2), 127-145. https://doi.org/10.1504/ijtel.2020.106282

\section{$7 \quad$ Authors}

Suryanti.is a Lecturer, Researcher, at Universitas Negeri Surabaya, J1. Campus Lidah Lakar Santri Surabaya 60213, Indonesia. Email: suryanti@unesa.ac.id. ORCID Suryanti: https://orcid.org/0000-0003-0341-2716.

Wahono Widodo. is a Lecturer, Researcher, at Universitas Negeri Surabaya, J1. Ketintang Surabaya 60231, Indonesia. Email: wahonowidodo@unesa.ac.id. ORCID Wahono Widodo: https://orcid.org/0000-0003-3636-8571.

Yoyok Yermiandhoko. is a Lecturer, Researcher, at Universitas Negeri Surabaya, Jl. Campus Lidah Witan Lakar Santri Surabaya 60213, Indonesia. Email: yoyokyermiandhoko@unesa.ac.id.

Article submitted 2020-02-10. Resubmitted 2020-09-26. Final acceptance 2020-09-26. Final version published as submitted by the authors. 